MCW-121

\title{
REACTION RATE OF THE FLUORINATION OF URANIUM DIOXIDE AT A CONTINUOUSLY INCREASING TEMPERATURE
}

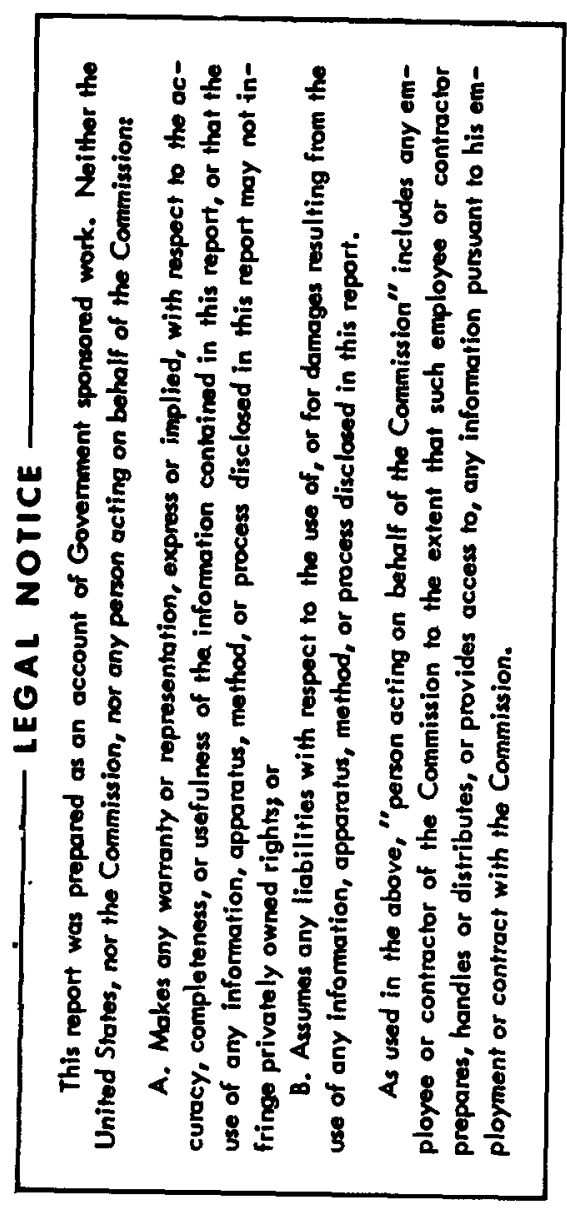

\author{
by \\ C. W. Kuhlman \\ July 19,1948 \\ Mallinckrodt Chemlcal Works \\ st. Louls, Missour1 \\ Work done by: \\ Dr. C. D. Barrington \\ $\mathrm{Mr}$. C. W. Kuhlman \\ Mr. C. F. Ritchie \\ Mr. J. Stevenson
}

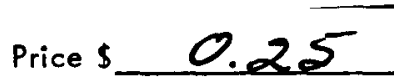

Available from the

Office of Technical Services

Department of Commerce

Washington 25, D. C.

Technical Information Division, Oak R1dge Operations

AEC, Oak Rldge, Tenn., 11-5-48--65-A607 


\section{DISCLAIMER}

This report was prepared as an account of work sponsored by an agency of the United States Government. Neither the United States Government nor any agency Thereof, nor any of their employees, makes any warranty, express or implied, or assumes any legal liability or responsibility for the accuracy, completeness, or usefulness of any information, apparatus, product, or process disclosed, or represents that its use would not infringe privately owned rights. Reference herein to any specific commercial product, process, or service by trade name, trademark, manufacturer, or otherwise does not necessarily constitute or imply its endorsement, recommendation, or favoring by the United States Government or any agency thereof. The views and opinions of authors expressed herein do not necessarily state or reflect those of the United States Government or any agency thereof. 


\section{DISCLAIMER}

Portions of this document may be illegible in electronic image products. Images are produced from the best available original document. 


\section{GOWFHENTHAT}

2

SUMMARY

Using an apparatus described in a preceding peper the reaction rate of the fluorination of Uranium Dioxide by Hydrofluoric acid was measured under the condition of a gradualiy increasing temperature. Uranium tetrafluoride made in this way does not show caking although final reaction temperatures ranged as high as $700^{\circ} \mathrm{C}$. The rate of reaction was found to be greater than the rate measured under isothermal conditions at the highest temperature attained during the continuous increase as long as this final temperature is above $550^{\circ} \mathrm{C}$.

\section{PXPHERTMENTAL}

The apparatus described in a previous report was employed for these experiments. A 2,000 g sample of the same "standard" uranium dioxide used for the work reported in the above mentioned report was placed in the furnace, and the apparatus swept free of alr with nitrogen. The furnace was then heated to about $200^{\circ} \mathrm{C}$, and the $\mathbb{H F}$ flow substituted for the nitrogen. The temperature of the furnace was then continuously increased as the reaction proceeded until a desired maximum was reached. If the reaction was not complete at this point the furnace was maintained at the desired temperature until reaction reached completion. The progress of the fluorination was followed ais described previously.

At the completion of the run, the sample was cooled in an atmosphere of $\mathrm{HF}$ to $200^{\circ} \mathrm{C}$ and in $\mathrm{H}_{2}$ to below $100^{\circ} \mathrm{C}$ before it was withdrawn for observation.

The results of four runs differing in the rate at which the temperature was increased are tabulated below and plotted in figures 1 \& 2 . The temperature time curve are denoted by outline points and the fluorination curves by solid polnts.

Run 1 (200 - 655 $\left.{ }^{\circ} \mathrm{C}\right)$

$\begin{array}{lcc}\text { Time } & \text { Temperature } & \frac{\Delta \mathrm{W} \times 100}{326} \\ & & 0 \% \\ 0 \text { min. } & 200^{\circ} \mathrm{C} & 10.0 \\ 5 & 301 & 16.6 \\ 8 & 350 & 20.4 \\ 10 & 385 & 31.6 \\ 15 & 445 & 42.2 \\ 20 & 500 & 51.8 \\ 25 & 542 & 61.0 \\ 30 & 575 & 70.0 \\ 35 & 604 & 77.8 \\ 40 & 630 & \end{array}$

\section{folintuetrint}



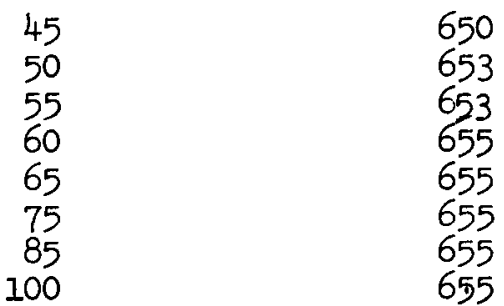

83.7

87.0 90.0 92.9 95.1 97.7 99.2 99.2

Run $2\left(190-535^{\circ} \mathrm{C}\right)$

Time

Temperature

$\frac{\Delta W \times 100}{326}$

$\begin{array}{lc}0 \text { min. } & 190^{\circ} \mathrm{C} \\ 5 & 208 \\ 10 & 255 \\ 15 & 292 \\ 20 & 325 \\ 25 & 355 \\ 37 & 408 \\ 48 & 442 \\ 60 & 46.5 \\ 75 & 485 \\ 90 & 498 \\ 105 & 512 \\ 120 & 520 \\ 135 & 525 \\ 150 & 530 \\ 180 & 533 \\ 210 & 533 \\ 240 & 534 \\ 270 & 534 \\ 300 & 534 \\ 345 & 535\end{array}$

$0 \%$ 3.38

7.37

12.3

19.9

27.0

36.2

44.6

52.9

63.0

69.7

76.0

81.5

84.9

88.1

91.8

95.2

96.3

97.8

98.5

98.8

Run $3\left(210-738^{\circ} \mathrm{C}\right)$

Time

Temperature

$\frac{\Delta W \times 100}{326}$

0 min.
4
6
8
12
16
21
27
34

$210^{\circ} \mathrm{C}$
293
325
357
415
455
505
555
600

0 8.59 12.89 19.6 25.8 33.8 44.5 55.5 68.2 


$\begin{array}{lll}40 & 630 & 77.7 \\ 46 & 655 & 84.8 \\ 51 & 672 & 90.7 \\ 55 & 683 & 93.6 \\ 60 & 695 & 96.8 \\ 65 & 707 & 97.1 \\ 70 & 715 & 97.1 \\ 76 & 725 & 97.7 \\ 90 & 738 & 97.7\end{array}$

Run 4(250-650 $\left.0^{\circ} \mathrm{C}\right)$

Time

Temperature

$\frac{\Delta W \times 100}{326}$

0
4
8
12
17
24
36
45
59
70
80
85
91
102
110
120

$250^{\circ} \mathrm{C}$
265
312
350
395
445
510
547
585
605
622
626
632
640
645
650

$0 \%$

$$
6.45
$$$$
12.6
$$

20.6

27.9

37.2

54.9

64.8

77.2

86.4

92.8

95.6

96.9

97.9

98.4

98.4

Uranium tetrafluoride made by this technique was very easily broken into a granular powder in contrast to material made 1sothermally at temperatures above $500^{\circ} \mathrm{C}$. The mechanism responsible for this caking phenomenon is unknown at present.

In the following table the time required for complete reaction as determined from curves in f1gures 1 \& 2 , the temperature of the furnace at complete reaction, and the time required to carry the reaction to completion under isothermal conditions at approximately the same maximum temperature are recorded. 
Increasing Temperature

$\begin{array}{lrc}\text { Run } & \begin{array}{c}\text { Time for } \\ \text { Complete } \\ \text { Reaction }\end{array} & \begin{array}{c}\text { Temperature } \\ \text { at } \\ \text { Completion }\end{array} \\ 1 & 85 \text { min. } & 650^{\circ} \mathrm{C} \\ 2 & 345 & 535 \\ 3 & 60 & 695 \\ 4 & 95 & 640\end{array}$

Constant Temperature

Time for
Complete
Reaction
100 min.
210
70
100

The reaction was completed in a shorter time when the temperature was increased during the fluorination in the three runs with the highest final temperature. It is believed that there is a correlation between this increased reaction rate and the absence of caking in the product. It is very plausible that the process of caking decreases the diffusion rates of the two gases ( $\mathrm{HF}$ and $\mathrm{H}_{2} \mathrm{O}$ ) through the $\mathrm{Balld}$ serving to decrease the reaction rate. When the reaction is carrled out at constant temperature below $550^{\circ} \mathrm{C}$, caking is less severe hence the reaction rate is not improved by a gradual temperature increase. 


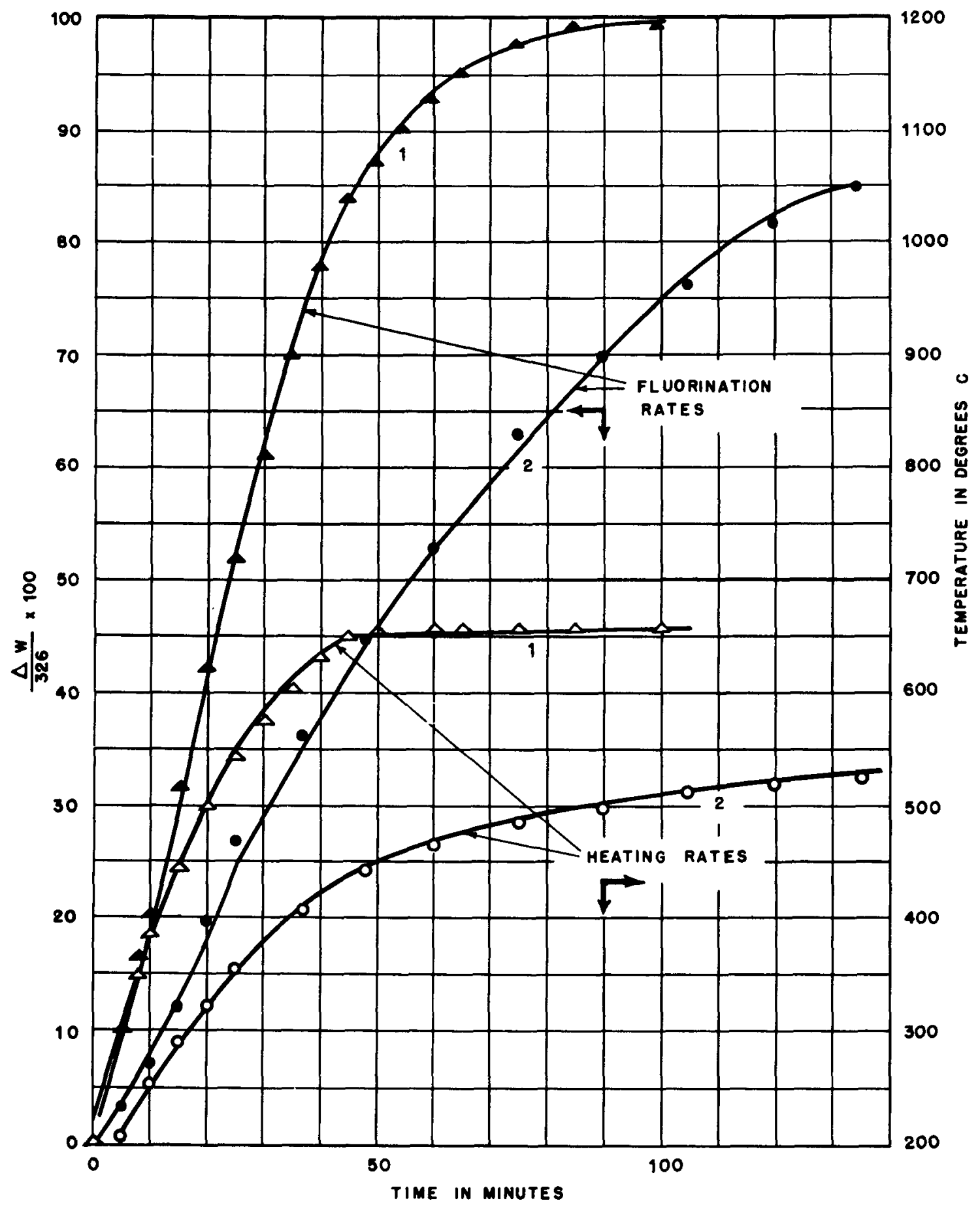

Figure 1.

- Guinturitiniles

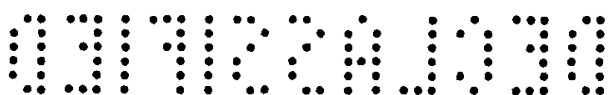




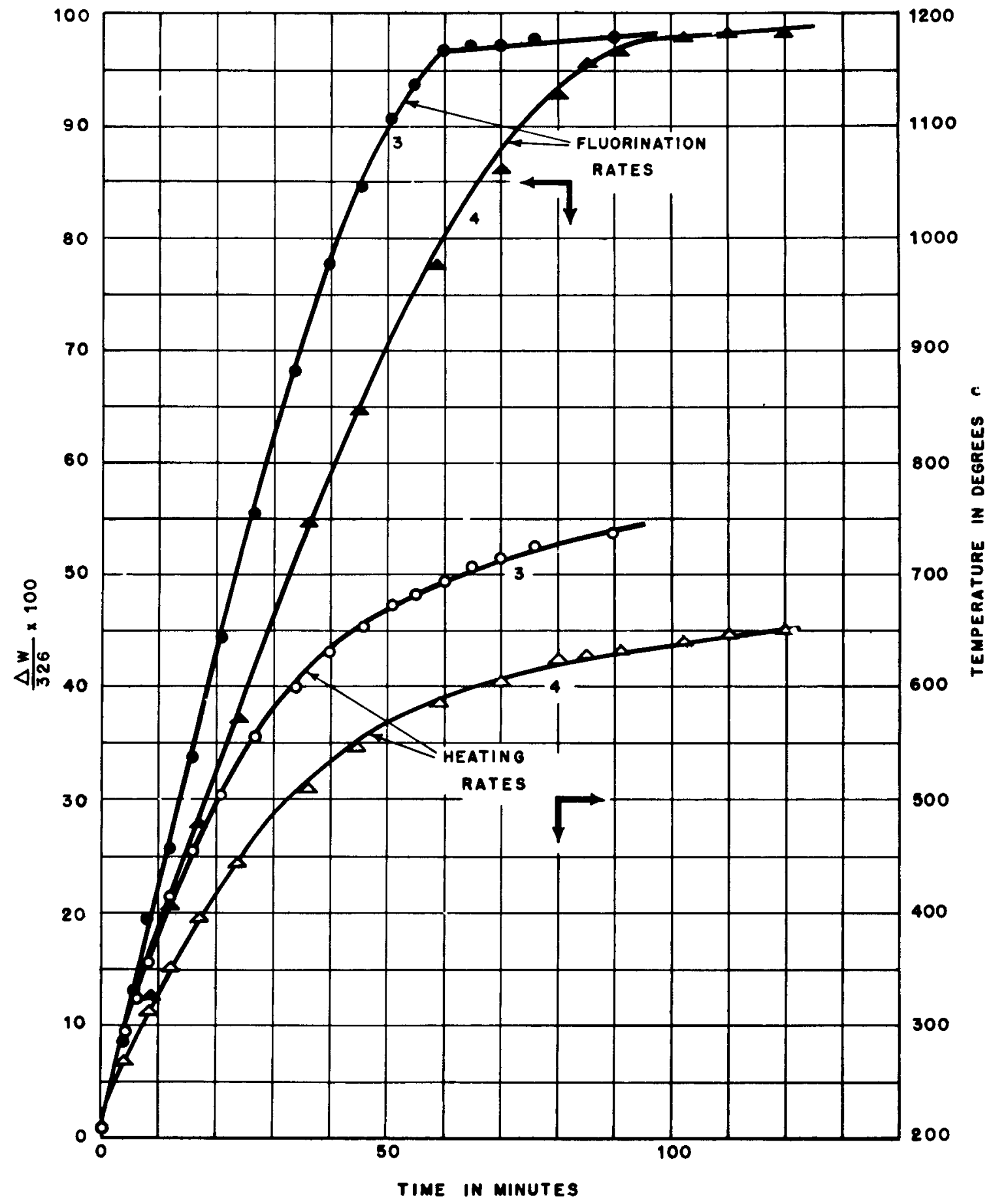

Figure 2.

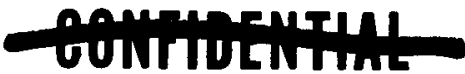



